\title{
Classification of Diseases of The Urinary System using an Expert System
}

Dacyr Dante de Oliveira Gatto ${ }^{1}$, Nove de Julho University, São Paulo, Brazil

João Victor Oliveira Mendonça Reis², Nove de Julho University, São Paulo, Brazil

Leandro Rosa Pedro ${ }^{3}$, Nove de Julho University, São Paulo, Brazil

Winicios Alves dos Santos ${ }^{4}$, Nove de Julho University, São Paulo, Brazil

Edquel Bueno Prado Farias ${ }^{5}$, Nove de Julho University, São Paulo, Brazil

\section{RESUMO}

Objetivo - Desenvolver e utilizar um Sistema Especialista (SE) para classificar doenças do sistema urinário.

Desenho / metodologia / abordagem - Os experimentos computacionais foram divididos em três fases, descritas a seguir: Fase A: Seleção do banco de dados: Procurou-se um banco de dados que contenha informações sobre doenças do sistema urinário. Fase B: Desenvolvimento e Implementação do Sistema Especialista: Planejaram-se regras e variáveis para a manipulação correta dos dados, e criou-se o Sistema Especialista implementando as regras e variáveis. Fase C: Validação do Sistema Especialista: Validado o Sistema Especialista por especialista.

Resultados - O Sistema Especialista foi validado, por um médico generalista e assim obteve-se êxito no momento dos testes e dos resultados. Assim concluindo-se, foi gerado o Sistema Especialista para classificar duas doenças (Cistite e Nefrite) do sistema urinário via validação de um médico generalista o qual confirmou a veracidade das informações composta no sistema desenvolvido com a finalidade de auxílio na área da medicina em um órgão específico.

Originalidade / valor - O desenvolvimento do presente trabalho possibilitou auxiliar o diagnóstico específico de duas doenças do sistema urinário. Com o auxílio do Sistema Especialista, permitiu-se ao profissional ter assertividade ao diagnosticar doenças do sistema urinário dos pacientes.

Palavras-chave - Sistema Urinário; Sistema Especialista; Inteligência Artificial; Apoio Ao Diagnostico.

\section{ABSTRACT}

Purpose - Develop and use an Expert System (ES) to classify diseases of the urinary system.

Design/methodology/approach - Computational experiments were divided into three phases, as described: Phase A: Database selection: We searched for a database that contains information on diseases of the urinary system. Phase B: Development and Implementation of the Expert System: Rules and variables were planned for the correct data manipulation, and the Expert System was created by implementing the rules and variables. Phase C: Validation of the Expert System: Expert System validated by specialists.

Findings - The Expert System was validated by a general practitioner and, as such, was successful while carrying out the tests and results. In conclusion, the Expert System was generated to classify two diseases (Cystitis and Nephritis) of the urinary system. This was validated by a general practitioner who confirmed the accuracy of the information within the system developed and aimed of assisting the field of medicine for a specific organ.

Originality/value - The development of the present work has made it possible to assist the specific diagnosis of two diseases of the urinary system. With the assistance of the Specialist System, professionals can be more confident when diagnosing diseases of the urinary system in patients.

Keywords - Urinary System; Expert Systems; Artificial Intelligence; Support to The Diagnosis.

1. Av. Professor Luiz Ignácio Anhaia Mello, 1363 - Vila Prudente, São Paulo - SP, 03155-000, dacyrgatto@terra.com.br; https://orcid.org/0000-0003-2146-4819; $\quad 2 . \quad$ joaoreisit@gmail.com; $\quad$ https://orcid.org/0000-0002-4236-1846; 3. leandrodarosapedro@gmail.com; https://orcid.org/0000-0001-6596-7894; 4. winiciosalves@gmail.com; https://orcid.org/00000001-7923-6961; 5. edquel.prado@live.com; https://orcid.org/0000-0002-7490-8148.

GATTO, D.D.O.; REIS, J.V.O.M.; PEDRO, L.R.; SANTOS, W.A.; FARIAS, E.B.P. Classification of Diseases of The Urinary System using an Expert System. GEPROS. Gestão da Produção, Operações e Sistemas, v.16, n²4, p. 74 - 87, 2021.

DOI: http://dx.doi.org/10.15675/gepros.v16i2.2747 


\section{INTRODUCTION}

In the human body, the evaluation of glomerular filtration (GF) represents one of the ways to determine renal function, a reduced GF is considered a good index of renal function (FILHO, 2004).

Due to the functioning of the urinary tract within the body, it can be easily subjected to infectious agents, leading to various infections, resulting in some diseases capable of preventing its proper functioning, and may even lead to death (NUNES, 2007).

Among the diseases that affect the urinary system, cystitis, a type of urinary infection defined by Johnson (1991) as a bladder infection, can be mentioned. Its symptoms are caused by inflammation of the bladder and urethra, which can cause pain and burning during and after urination, in addition to pain in the abdomen. Another type of urinary tract infection is acute nephritis, known as pyelonephritis.

According to Ferreira (2014), acute nephritis is a manifestation of an important indicator of infection of the urinary system due to the variety of symptoms provided, such as: back pain, sudden fever, malaise and cases of cloudy urine or hematuria (blood in the urine).

For Rodrigues and Barroso (2011) there are several factors that are considered predisposing to the occurrence of urinary infections, where a certain anatomical site of the urinary system can be affected, generating an infection.

Among the methods to classify urinary infections, there are uncomplicated methods, these being when they involve the normal urinary system, and complicated methods, when the system presents structural or functional changes (MARTINS et al., 2009). For this fact, it is concluded that the correct classification of these infectious diseases, can facilitate for the treatment of the patient.

According to Slack (1997), the use of Information Technology (IT) in hospitals and the growth in the use of computers in several other sectors has created high expectations for most health organizations. The IT has been innovating in several areas, in the case of IT health, it is a knowledge still under development, seeking to so beneficial improvements that can make a difference in the medical field. (CARVALHO, 2002).

With the advances in IT, the volume and complexity of the data are increasing, therefore, a Decision Support System (DSS) can assist in decision making, since in the 
medical area, the main objective of DSS is assist the medical service of diagnostics and prognosis in health units, allowing the health professional to interact with the system, and have the assistance in supporting the screening, diagnosis or monitoring of a patient (CASCÃO, 2011).

An important area of computer science, used in the DSS is the Artificial Intelligence, which possess subsidies for medical decision making, promoting agility and efficiency to the attention dure (BALLICO et al., 2018).

An Expert System needs variables, rules and a language with the expressions of the knowledge provided by the specialist; a specific knowledge base to store the desired applications, which can be directly provided by a specialist or accumulated by the system at the end of the experiments; an inference engine, a program that explores the knowledge of the previous base, considering the base as a source of information, thus having scope for changes (MENDES, 1997).

For Andrade (1999), being based on a heuristic search, the Expert System manipulates large knowledge bases that are applied in the solution of a well-defined problem. Being able to issue a decision, which is justified through the knowledge provided that confronts the cases, facts and conclusions of the problem found in your knowledge base.

However, one must be able to acquire and improve new knowledge, improving its performance and creating skills to infer, represent and transfer specific knowledge to the users who manipulate it (SELLMER, 2013). In this context, the objective of this study is to classify diseases of the urinary system using the Expert System.

\section{THEORETICAL FOUNDATION}

\subsection{Information Systems in the Hospital Area}

Information systems (IS) have an increasing importance in the support provided to health professionals and patients themselves, with the aim of making available and generating access to relevant information on health care, as well as promoting the quality of health services through of contextualized support for medical decisions by professionals and patients themselves (GOMES, 2011).

These first applications were computer systems for decision support, built from the 1960s and were, for the most part, focused on the problem of diagnosis. They were 
small-scale and developed for domains with a small number of hypotheses and limited evidence, such as acute abdominal pain or acute renal failure. In larger domains these simplifications, in general, produced mathematically incorrect results (HÖHER; LADEIRA; VICARI, 2000).

Jepsen (2003) argues that the health area is one of the last areas of application of IT in a generalized and organized way, such finding is due to the complexity of health services, as well as the difficulty of forming and defining joint competences in the two areas knowledge: health sciences and computer sciences.

\subsection{Urinary System Infections}

The kidneys together with the urinary tract are organs that make up the urinary system, exercising multiple functions, being didactically characterized as filtration, resorption, homeostasis, endocrinological and metabolic functions. Its primary function is the maintenance of homeostasis, regulating the internal environment predominantly by the reabsorption of filtered substances and ions in the glomeruli and excretion of other substances (COSTA; LIMA; SODRÉ, 2007).

Due to the functions of glomerular filtration of the urinary system, some symptomatic infections of the urinary system are among the most frequent bacterial infections in humans, being the second most common infection in the general population, most common in adult female patients. In the case of children, particularly in the first year of life, urinary tract infection is also more common in females, with pyelonephritis predominating, which recurs in most cases due to the presence of structural and / or functional abnormalities, such as vesico-ureteral reflux, uni or bilateral (LOPES; TAVARES, 2005).

In men, the length of the urethra, increased urinary flow and the prostatic antibacterial factor are protective factors against infections of the urinary system (NUNES et al., 2 016). However, prostate hypertrophy, causing obstruction to the urinary flow, leads to an increase in the incidence of infections in the urinary system, being common in men over the age of fifty. This can be considered as the most important factors related to the host: age, behavioral factors, diabetes, spinal injury, bladder catheterization and pregnancy. (MARTINS et al., 2009).

Infections of the urinary system are responsible for the increased morbidity and 
mortality of patients, as well as the length of hospital stay and care costs (ALMEIDA; SIMÕES; RADDI, 2007). In addition, infections of the urinary system are characterized by the presence of bacteria in any part of the system (kidneys, ureters, bladder), except the urethra.

Depending on the anatomical site affected, the infection is given different names. For example, the infection caused by the presence of bacteria in the urine of the renal pelvis is called pyelonephritis, while in the bladder it is called cystitis (RODRIGUES; BARROSO, 2011).

Pyelonephritis is an inflammatory process of the nephrons, small functional components of the kidneys. One consequence of this inflammation is the decreased ability of the kidney to filter the blood. Thus, acute nephritis originating from the renal pelvis, also called pyelonephritis, is mainly related to the rise of an infectious process in the lower urinary system (BATISTA, 2002).

In cases of pyelonephritis, sudden fever and chills may be observed, accompanied by low back pain on one or both sides, which worsen the percussion wrist (basic technique for physical examination). There may also be diffuse abdominal pain, with nausea and vomiting (BATISTA, 2002). Another disease, acute cystitis, infection of the lower urinary system, involving the bladder has as symptoms dysuria, polluria, nicturia, suprapubic pain when urinating and urinary urgency, such symptoms among others are the main reasons that lead clinical patients to seek medical assistance (MATEJCZYK et al., 2010).

On the differential diagnosis of these infections of the urinary system includes vaginitis (inflammation of the vaginal mucosa) and urethritis (inflammation of the urethra). In the case of interstitial cystitis it is a differential diagnosis that should be remembered mainly in the elderly, for acute pyelonephritis, it must in turn be differentiated from chronic pyelonephritis, which is a common cause of interstitial tubule disease due to recurrent infections, such as those that occur in patients with kidney obstruction due to stones or urethral vesic reflux (MARTINS et al., 2009).

According to Martins et al. (2009), in the case of asymptomatic infections, it is a microbiological diagnosis, being more common among people with diabetes mellitus, the elderly and women. It is worth mentioning that sexual activity influences its presence. However, this type of asymptomatic bacteriuria should generally not be treated, with the 
exception of specific groups of patients, for example, patients who will undergo urological surgery.

For patients with uncomplicated urinary system infections, their diagnosis is based on clinical history, and complementary tests are not indicated (type 1 urine and urine culture), however in the case of women there are some conditions to be excluded for this, such as: immunosuppression, symptoms suggestive of vaginitis, abdominal pain, among others In all other patients, diagnostic confirmation with laboratory tests is necessary, in addition it is of great importance to mention that infections in the urinary system in men are considered complicated infections, as they are often associated with structural abnormalities of the urinary system (MARTINS et al., 2009).

Therefore, the study of the function and the diverse pathological processes of the urinary system, has aroused the interest of many researchers in several areas of knowledge, including the field of the development of tests that help doctors to establish an early diagnosis, in addition to classifying the disease base, obtain a safe prognosis and monitor drug therapy (COSTA; LIMA; SODRÉ, 2007).

\subsection{Expert System}

According to Luxton (2014), an Expert System (ES), is an Artificial Intelligence (AI) technique that deals with complex real-world problems that require the analysis and interpretation of a human specialist, solves these problems through the use of a computational model of reasoning of the human specialist, in order to arrive at the same conclusions as this (human) specialist would arrive, without the risk of failures, loss of performance, forgetfulness, among other defects and emotions, if faced with a similar problem.

An ES is software that can provide knowledge to solve problems in an application area defined in the same way that experts would do, complexity is understood based on a set of filtered information to facilitate decision making and assertively direct the root cause of the problem. The ESs have the purpose of helping in the most accurate, fast, and effective direction to diagnose a disease, reducing the time to investigate the symptoms presented by the patient according to (BRAGA; SILVEIRA, 2009).

According to Braga and Silveira (2009), the solution to a problem proposed by an ES is aimed at a specific area of knowledge, provided by people who are specialized in 
this area. This acquired knowledge allows the issuing of justified and supported decisions, based on an information base, acting as if it were a human specialist in a certain area of knowledge.

Kasabov (1996) states that ESs have been used successfully in almost all fields of human activity, including engineering, science, medicine, agriculture, industry, education and training, business, finance and design. An expert system (ES) needs to have its knowledge acquisition process supervised, that is, specialists in the field of knowledge of performance and developers of the computation part to build the system (CARVALHO, SHELLMER; GASPAR, CARINA, 2013).

According to Mastella and Abel (2004) knowledge is all that is used to act and create new information. Knowledge includes information about the domain and how that information is used to solve problems.

Thus, there are ways to use knowledge, according to Albagli and Maciel (2004). The ability to generate and apply knowledge, according to the needs and specificities of each organization, country, and locality, is, therefore, central. Thus, as important as the ability to produce new knowledge is the ability to process and recreate knowledge, through learning processes.

The main characteristic of an ES is to issue a decision, supported by justified knowledge from an information base, as a specialist in a determined area of human knowledge (COSTA; AGUILLERA, 2013).

According to Farias and Sassi (2018) The chosen approaches must be: the analysis of the database with solutions applied within the observation domain and unstructured interviews with specialists so that they feel free to suggest new types of knowledge.

The representation of knowledge by production rules is based on a set of rules to describe conditions and actions. The rules are stored as a collection of IF-THEN statements (HEINZLE, 1995).

According to Farias and Sassi (2018) from their observations of related works (LUGER, 2013; GUPTA; SINGHAL, 2013; ADELI, 2014), it is clear that the typical architectural pattern of an SE has an interface user interface, an acquisition interface and the explanation module, in addition to the knowledge base and inference engine. Figure 1 illustrates the architecture of an Expert System: 
Figure 1 - Expert System Architecture.

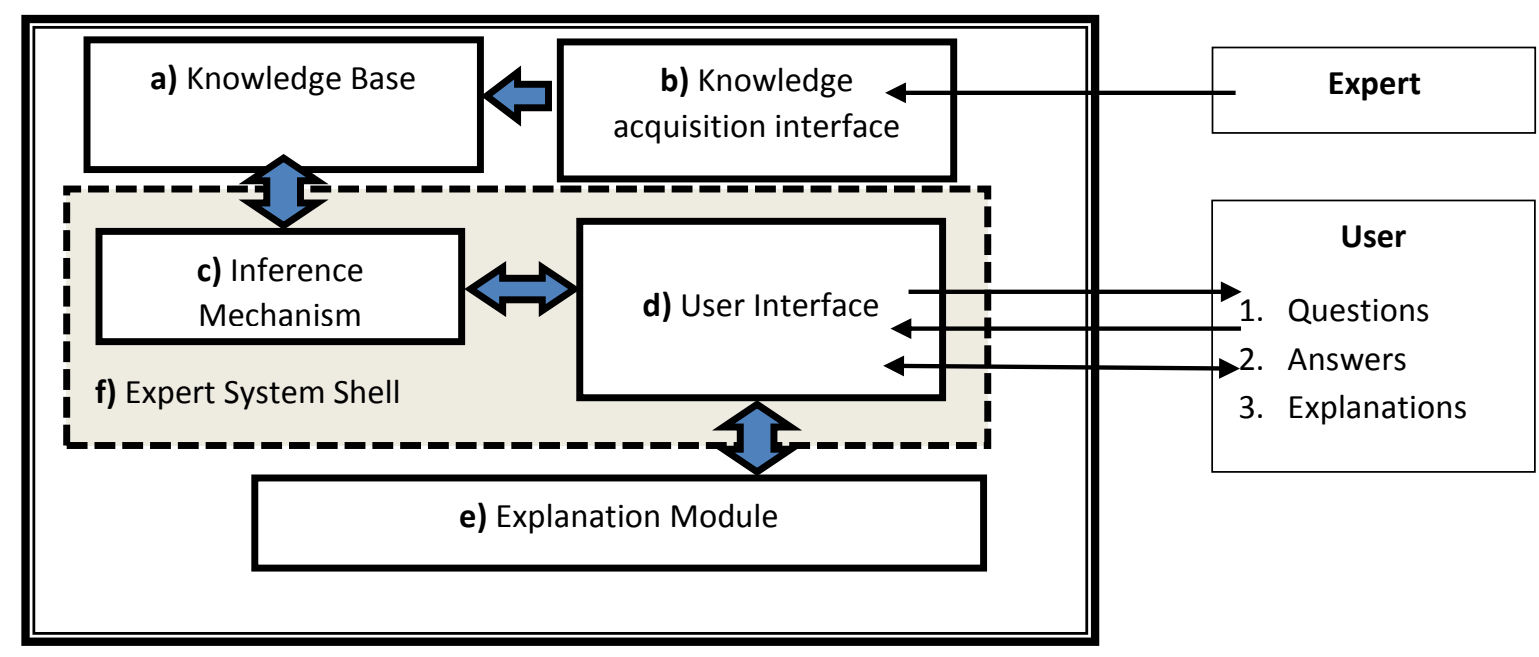

Source: Farias; Sassi (2018).

Gatto and Sassi (2018) present a description of the SE architecture supported by several authors, presenting a very similar structure as described below: a) Knowledge base; b) Interface with the User; c) Mechanism or Inference Engine.

The union of the inference mechanism and the user interface is better known as the Core of the Expert System or Shell. The usefulness of a Shell is to enable the rapid prototyping of a specialist system (SALIH; ABRAHAM, 2013; SOUZA, 2017).

The urinary system disease classification SE was modeled with the aid of the Expert Sinta (ExSinta) software, which is a Shell that uses AI techniques for automatic ES generation. The ExSinta uses a representation model based knowledge on production rules and aims to simplify the SE implementation by using a shared inference engine and building automatic screens and menus (LIA 1999; FARIAS; SASSI, 2018, GATTO; SASSI, 2018).

ExSinta uses production rules to model human knowledge, ideal for problems in which a given solution must be reached from a set of selections. The rules are based on IF-THEN-ELSE conditions (IF-OR-THEN). Rules are developed based on the variables and objectives of the problem to which they are proposed as a solution.

The development process leads to a cycle, where each new passage leads to another level of depth to refine the knowledge already acquired and store this knowledge in a 
knowledge base.

\section{METHODOLOGICAL PROCEDURES}

The computational experiments were divided into three phases, described below:

a) Phase A: Database selection: We searched for a database that contains information on diseases of the urinary system.

b) Phase B: Development and Implementation of the Expert System: Rules and variables were planned for the correct handling of data, and the Expert System was created implementing the rules and variables.

c) Phase C: Validation of the Expert System: Validated the Specialist System by specialists. The following are shown in Figure 2 phases of computational experiments:

Figure 2 - Phases are experiments.

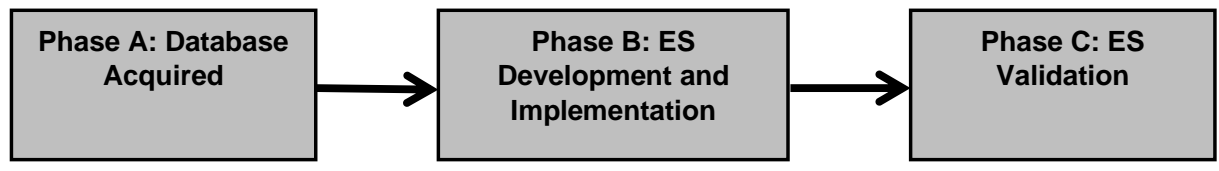

Source: Authors (2018).

In Phase A - Database Selection: data were extracted from the data base: "Acute inflammations Data Set", which in turn has the idea to prepare comparative data of the following diseases: inflammation of the bladder and acute nephritis.

In Phase B - Development and implementation of the Expert System: the ES was developed, using the ExSinta software. The software proportionate support clinical diagnosis by means of variables and developed rules. The rules and variables were structured according to the knowledge extracted from the database in the previous phase.

In Phase C - Validation Expert System: the ES was validated by the health experts, thereby ascertaining, classifying the two diseases urinary system (acute nephritis and inflammation of the bladder). The health professional who validated the ES is a general practitioner.

The ES knowledge base was implemented in the form of rules, from consultations with a general practitioner, in a total of 16 rules. Such rules were implemented in the development of the system. The knowledge base was generated from the "UCI Machine 
Learning Repository: Data Sets". Using correlation information and data extracted from the "Acute Inflammations Data Set" database.

In the process of creating the rules, the following approaches were used: a) Unstructured interview with the general practitioner; b) Literature search; c) Creation of rules and variables from ExSinta; d) Validation and reduction; e) Definition of the most important attributes ; f) Verification of the rules and validation of the system .

The variables were inserted in the ExSinta knowledge base, completely manual work. Each variable received a value, which can be numeric, single-valued or multivalued. Were also created s five variables goal, which is the goal of the ES. In this case, the objective is the identification of two diseases of the urinary system, decision support recommended by the general practitioner, and an objective if it does not identify any of the diseases. Figure 3 shows a sample of the generated rules.

Figure 3 - Production Rules.

\begin{tabular}{|c|c|}
\hline $\begin{array}{l}\text { Regra } 1 \\
\text { SE } \\
\text { E } \\
\text { E } \\
\text { ENTAOO }\end{array}$ & $\begin{array}{l}\text { Hemodinamicamente = Sim } \\
\text { disúria = Sim } \\
\text { Sexo = Feminino } \\
\text { cistite = Sim CNF } 50 \%\end{array}$ \\
\hline $\begin{array}{l}\text { Regra } 2 \\
\text { SE } \\
\text { E } \\
\text { E } \\
\text { ENTÃo }\end{array}$ & $\begin{array}{l}\text { Hemodinamicamente }=\operatorname{Sim} \\
\text { Urinar pouco }=\operatorname{Sim} \\
\text { Sexo = Feminino } \\
\text { cistite }=\operatorname{Sim} C \mathrm{NF} 50 \%\end{array}$ \\
\hline
\end{tabular}

Source authors (2019).

The user interface was developed presenting the screens:

When starting ES, a welcome screen is displayed, showing the purpose of the program to the user. After the welcome screen, the user is redirected to the questioning screen for the classification of diseases. In Figure 4, we can see an example of questioning made by the system to the user. 
Figure 4 - Example of questioning made to the user in the ES.

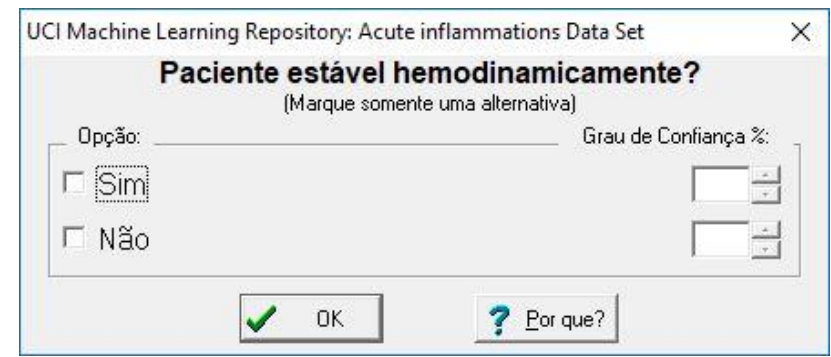

Source: Authors (2019).

The user will answer the existing questions until the SE premises have been reached until reaching the result, as shown in Figure 5:

Figure 5 - Example of result referring to the consultation carried out in the ES.

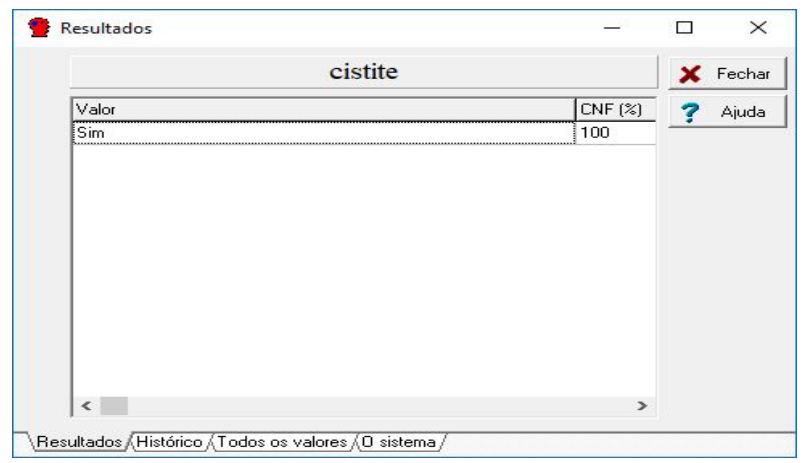

Source: Authors (2019).

\section{RESULTS AND DISCUSSION}

The production rules generated had an interesting level of precision in the execution, correctly indicating the questions and generating the knowledge base. In ES, 16 rules were implemented in total.

Some questions programmed in the ES have degrees of confidence to guarantee the accuracy of the result, which are guided according to the data entered by the ES user. With the implementation of the ES it was possible to identify patients with diagnosed with Cystitis; identify patients with diagnosed with Pyelonephritis; Identify the need to order Ultrasound 
and Urine tests 1 ; identify the need to request blood culture exams and obtain more accurate results using only attributes that are relevant to the diagnosis.

The development of the present work made it possible to assist the specific diagnosis of two diseases of the urinary system. With the help of the ES, the professional could be assertive when diagnosing diseases of the patients' urinary system.

The ES carries out its tasks via the "Inference Engine", making deductions, using its source of knowledge acquired and periodically improved as a basis, incorporating human action, making predictions and viewing certain difficulties or hidden data in an analysis, with the features of IA coming to completion faster and closer to the ideal . To experiment and tests the UCI database (Machine Learning Repository) referring to urinary disease was used.

\section{CONCLUSION}

The ES developed according to the previously mentioned has delimitations that can prevent its flexibility in its usefulness. In the format in which the SE was generated, it is necessary to use the ExSinta platform to execute all information on rules and variables related to the diagnosis of the urinary system.

In the medium term, it is recommended to host the application on the Web, ensuring its availability 24 hours a day, classifying it as a mission-critical medical tool. In the long run, it is suggested to have a statistical report feature, making it possible to generate graphs for better understanding and study of data related to urinary disease.

The ES was validated by a general practitioner and thus was successful at the time of tests and results.

Thus, concluding this article, the ES was generated to classify two diseases (Cystitis and Nephritis) of the urinary system via validation by a general practitioner. Confirming the veracity of the information composed in the system developed with the purpose of helping in the field of medicine in a specific organ. 


\section{References}

ADELI, H. Expert systems in construction and structural engineering. CRC Press, 2014.

ALBAGLI, S.; MACIEL, M. L. Informação e conhecimento na inovação e no desenvolvimento local. Ciência da informação, v. 33, n. 3, 2004.

ALMEIDA, M. DE C.; SIMÕES, M.; RADDI, M. S. G. Ocorrência de infecção urinária em pacientes de um hospital universitário. Revista de Ciências Farmacêuticas Básica e Aplicada, p. 215-219, 2007.

ANDRADE, P. J. N. DE. Sistemas especialistas de apoio ao diagnóstico em medicina. Relações com o teorema de Bayes e com a lógica do raciocínio diagnóstico. Arquivo Brasileiro Cardiologia, v. 73, n. 6, p. 537-544, 1999.

BATISTA, C. S. Infecção do trato urinário na gestação-conduta. Femina, v. 30, n. 8, p. 553557,2002

CARVALHO, A. DE O. Informática em saúde e fatores críticos de sucesso: um estudo no INCOR. Tese (Doutorado em Administração de Empresas) - Biblioteca Digital, FGV, 2002. Avaiable: http://bibliotecadigital.fgv.br/dspace/handle/10438/4466. Acess on may, 2020.

CASCÃO, L. V. C. Modelos de inteligência computacional para apoio a triagem de pacientes e diagnóstico clínico de tuberculose pulmonar. Dissertação 210f. 2011. (Mestrado em Engenharia Elétrica) - Universidade Federal do Rio de Janeiro, 2011.

DA COSTA, K. A. P.; AGUILlERA, H. R. Análise e desenvolvimento de Sistema Especialista para Service Desk Utilizando Conceitos de ITIL. RETEC-Revista de Tecnologias, v. 5, n. 1, 2013.

FARIAS, E. B. P.; SASSI, R. J. Framework ITIL e Inteligência Computacional na padronização do atendimento do Service Desk de um Hospital Público. Revista Eletrônica Gestão \& Saúde, [S.1.], v. 9, n. 2, p. 219 - 233, 2018.

GATTO, D. D. O.; SASSI, R. J. Classificação de Criticidade de Versão de Software Apoiada por Sistema Especialista. In: SIMPÓSIO DE ENGENHARIA DE PRODUÇÃO. n. 25, 2018. Anais... SIMPEP, Bauru, SP, 2018.

GOMES, D. DOS S. Inteligência Artificial: Conceitos e Aplicações. Olhar Científico, v. 1, n. 2, p. 234-246, 2011.

GUPTA, S; SINGHAL, R. Fundamentals and characteristics of an expert system. International Journal on Recent and Innovation Trends in Computing and Communication, v. 1, n. 3, p. 110-113, 2013.

HEINZLE, R. et al. Protótipo de uma ferramenta para criação de sistemas especialistas baseados em regras de produção. 1995. Avaiable: https://repositorio.ufsc.br/xmlui/handle/123456789/157957. Acess on may 2020.

JEPSEN, T. IT in Healthcare: Progress Report, IT Professional, IEEE Computer Society Jan-Feb, pp 8-14, 2003.

JOHNSON, C. C. Definitions, classification, and clinical presentation of urinary tract infections. The Medical clinics of North America, v. 75, n. 2, p. 241-252, 1991.

KASABOV, N, K. Foundations of neural networks, fuzzy systems, and knowledge 
engineering, A Bradford Book. London, England The MIT Press, 1996.

LIA, Laboratório de Inteligência Artificial. Expert SINTA: uma ferramenta para criação de sistemas especialistas. Universidade Federal do Ceará, 1999.

LOPES, H. V.; TAVARES, W. Diagnóstico das infecções do trato urinário. Revista da Associação Médica Brasileira, v. 51, n. 6, p. 306-308, 2005.

LUXTON, G.W. G.; STARR, D.A. KASHing up with the nucleus: novel functional roles of KASH proteins at the cytoplasmic surface of the nucleus. Current opinion in cell biology, v. 28, p. 69-75, 2014.

MARTINS, H.; NETO, R.; NETO, A.; VELASCO, I. Emergências Clínicas. Disciplina de Emergências Clínicas da FMUUSP.4 Edição. Barueri. Manole, 2009.

MASTELlA, L. S.; ABEL, M. Técnicas de aquisição de conhecimento para sistemas baseados em conhecimento. Curso de Bacharelado em Ciências da computação, Universidade Federal do Rio Grande do Sul-Instituto de Informática, 2004.

MENDES, R. D. Inteligência Artificial: sistemas especialistas no gerenciamento da informação. Ciência da Informação, v. 26, n. 1., 1997.

NUNES, P. R.; FONINI, L. S.; OLIVEIRA, M. S.DE ; KATAGIRI, S.K. Prevalência e perfil de resistência bacteriana em infecções do trato urinário de pacientes ambulatoriais da Grande Porto Alegre, RS. Revista Brasileira de Análises Clínicas, v. 48, n. 3, supl. 01, p. 92-98., 2016.

NUNES, G. L. DA S. Avaliação da função renal em pacientes hipertensos. Revista Brasileira Hipertensão, v. 14, n. 3, p. 162-166., 2007.

RODRIGUES, F. J. B.; BARROSO, A. P. D. Etiologia e sensibilidade bacteriana em infecções do tracto urinário. Revista Portuguesa de Saúde Pública, v. 29, n. 2, p. 123-131, 2011.

SALIH, A.; ABRAHAM, A. A review of ambient intelligence assisted healthcare monitoring. International Journal of Computer Information Systems and Industrial Management, v. 5, p. 741-750, 2013.

SELlMER, D.; CARVALHO, C. M. G.; CARVALHO, D. R.; MALUCELli, A. Sistema Especialista para apoiar a decisão na terapia tópica de úlceras venosas. Revista Gaúcha de Enfermagem, v. 34, n. 2, p. 154-162, 2013.

SLACK, W. V. Cybermedicine: how computing empowers doctors and patients for better health care. San Francisco, CA: Jossey-Bass Publishers, 1997.

SODRÉ, F. L.; COSTA, J. C. B.; LIMA, J. C. C. Avaliação da função e da lesão renal: um desafio laboratorial. Jornal Brasileiro de Patologia e Medicina Laboratorial, v. 43, n. 5, p. 329-337, 2007.

SOUZA, D. C. Sistema especialista baseado em regras ponderado por tendências aplicado ao monitoramento de processos industriais. Tese de Doutorado. 250f. 2017. Universidade Federal do Rio Grande do Norte, RN, 2017. 